\title{
Transcription of paternal Y-linked genes in the human zygote as early as the pronucleate stage
}

\author{
Asangla $A o^{1}$, Robert P. Erickson ${ }^{2}$, Robert M.L.Winston ${ }^{1}$ and Alan H. Handyside ${ }^{1}$ \\ Institute of Obstetrics and Gynaecology, Royal Postgraduate Medical School, London, UK, and Department of Pediatrics, \\ The University of Arizona, Tucson, USA
}

\section{Summary}

Global activation of the embryonic genome occurs at the 4- to 8-cell stage in human embryos and is marked by continuation of early cleavage divisions in the presence of transcriptional inhibitors. Here we demonstrate, using reverse transcriptase-polymerase chain reaction (RT-PCR), the presence of transcripts for two paternal $Y$ chromosomal genes, $Z F Y$ and $S R Y$ in human preimplantation embryos. $Z F Y$ transcripts were detected as early as the pronucleate stage, $20-24 \mathrm{~h}$ post-insemination in vitro and at intermediate stages up to the blastocyst stage. $S R Y$ transcripts were also detected at 2-cell to blastocyst stages. The expression of $S R Y$ and $Z F Y$ at these early stages and the faster cleavage rate of male embryos observed in many mammalian species focuses attention on the role of events in sex determination prior to gonad differentiation.

Key words: Preimplantation human embryo, RT-PCR, sex determination, SRY, ZFY

\section{Introduction}

Mammalian embryos, like those of lower vertebrates and invertebrates, are dependent on maternally inherited products from the oocyte for an initial period following fertilization prior to activation of the embryonic genome. The timing of the onset of embryonic genome expression differs in different species. In the mouse, embryonic expression is initiated at the mid 2-cell stage (Braude et al., 1979; Flach et al., 1982; Clegg \& Piko, 1982; Clegg et al., 1983a,b; Bolton et al., 1984). RNA synthesis (Clegg et al., 1983a) and transcription of major histocompatibility complex (Mhc) class I genes, however, have been detected as early as the 1-cell stage (Sprinks et al., 1993). In other species, embryonic gene transcription starts later at the 4-cell (pig, Tomanek et al., 1989) or 8-cell stages (cow,

All correspondence to: A. Ao, PhD, Institute of Obstetrics and Gynaecology, Royal Postgraduate Medical School, Hammersmith Hospital, Du Cane Road, London W12 0NN, UK. Telephone: 081-743-2030, ext 2084. Fax: 081-749-6973.

${ }^{1}$ Institute of Obstetrics and Gynaecology, Royal Postgraduate Medical School, London, UK.

${ }^{2}$ Angel Charity for Children Wings for Genetic Research, Steel Memorial Childrens Research Center, Department of Pediatrics and Department of Molecular and Cellular Biology, The University of Arizona, 1501 N. Campbell Avenue, Tucson, AZ 85724, USA.
Camouse et al., 1986; sheep, Crosby et al., 1988). In the human preimplantation embryo, major qualitative changes in polypeptide synthesis observed between the 4- and 8-cell stages are dependent on transcription, suggesting the onset of global expression of the embryonic genome at this stage (Braude et al., 1988). Compared with the mouse, however, there is very limited information concerning RNA synthesis and the molecular mechanisms that regulate the onset of transcription. Tesarik et al. (1988) showed $\left[{ }^{3} \mathrm{H}\right]$ uridine incorporation into nuclei and nucleoli at the 4-cell stage while mRNA for a specific embryonic product, chorionic gonadotrophin $\beta(\mathrm{hCG}-\beta)$, is first detected by in situ hybridisation at the 6-to 8-cell stage (Bonduelle et al., 1988). However, recently Tesarik \& Kopecny (1989) have shown $\left[{ }^{3} \mathrm{H}\right]$ adenine incorporation at the 1-cell zygote stage.

The timing of paternal gene transcription provides a marker for the activation of the embyronic genome in male embryos. Here we report the use of reverse transcriptase-polymerase chain reaction (RT-PCR) to search for Y-linked gene transcription in human preimplantation embryos. In placental mammals, sex determination is mediated by the presence of testes determining gene(s) encoded by the $Y$ chromosome. We have analysed the transcription of ZFY, a Y-coded 
zinc finger protein located adjacent to the sexdetermining region (Page et al., 1987) and SRY (Sry in mouse), the testes-determining factor (TDF: Sinclair et al., 1990; Gubbay et al., 1990). We demonstrate the presence of $Z F Y$ transcripts as early as the proncleate stage and SRY at the 2-cell stage (the earliest stage tested). The possible relationship between transcription of Y-linked genes at these early stages and the faster cleavage and development rate of male embryos observed in many mammalian species is discussed.

\section{Materials and methods}

\section{Embryo collection and culture}

Surplus human embryos were obtained with approval from patients undergoing in vitro fertilisation (IVF) or gamete intra-fallopian transfer (GIFT) procedures at the Wolfson Family Clinic, Hammersmith Hospital. Superovulation and oocyte retrieval were as described earlier (Rutherford et al., 1988). Oocytes were collected by vaginal ultrasound-guided aspiration and inseminated with prepared sperm (day 0). Oocytes were examined for pronuclei $19-20 \mathrm{~h}$ post-insemination and embryos were classified as 'normal' or 'polyspermic' depending upon the presence of two or more pronuclei, respectively. Fertilised zygotes were either harvested immediately or transferred to culture medium for further development as described earlier (Hardy et al., 1989).

This work has been approved by the Human Fertilization and Embryology Authority and the Research Ethics Committee of the Royal Postgraduate Medical School.

\section{Preparation of RNA from tissue samples}

Total RNA was prepared from human tissues using RNAzol $^{\mathrm{TM}} \mathrm{B}$ (Biogenesis Ltd) and poly $\mathrm{A}^{+}$RNA isolated using the 'Quick prep mRNA isolation kit' (Pharmacia Biotech). RNA was treated with RNasefree DNase for $20 \mathrm{~min}$ at $37^{\circ} \mathrm{C}$. From 0.1 to $0.05 \mu \mathrm{g}$ of RNA was added to reverse transcriptase reaction to synthesise cDNA.

\section{Reverse transcription-polymerase chain reaction (RT-PCR)}

The zona pellucida was removed from oocytes and embryos with a brief acid Tyrodes' treatment and the embryos washed thoroughly in phosphate-buffered saline (PBS). Oocytes and embryos of the same stage were pooled in an Eppendorf tube containing 5-10 $\mu \mathrm{l}$ lysis buffer (0.5\% NP40, $10 \mathrm{mM}$ Tris (pH 8.0), $10 \mathrm{mM}$ $\mathrm{NaCl}$ and $3 \mathrm{mM} \mathrm{MgCl}_{2}$ ) (Gilliland et al., 1990). The tubes were spun for $1-2 \mathrm{~min}$ and the supernatant containing the RNA used for cDNA synthesis in the presence $(R T+)$ or absence $(R T-)$ of reverse transcriptase. The final reaction mixture containing 3-8 $\mu \mathrm{l}$ of crude RNA, $50 \mathrm{mM}$ Tris- $\mathrm{HCl}(\mathrm{pH} \mathrm{8.3),} 75 \mathrm{mM} \mathrm{KCl}$, $3 \mathrm{mM} \mathrm{MgCl}, 10 \mathrm{mM}$ DTT, $0.5 \mathrm{mM}$ of each dNTP, $0.5 \mu \mathrm{g}$ of oligo(dT) ${ }_{12-18}$ primer, 1 unit of RNase $\mathrm{H}, 100$ units of M-MLV reverse transcriptase (BRL) which was incubated at $37^{\circ} \mathrm{C}$ for $1 \mathrm{~h}$. The reaction was terminated by heating at $95^{\circ} \mathrm{C}$ for $5 \mathrm{~min}$. Subsequent $30 \mu \mathrm{l}$ PCR reactions contained 5-10 $\mu \mathrm{l}$ reverse-transcribed cDNA, $10 \mathrm{mM}$ Trs- $\mathrm{HCl}, \mathrm{pH} 8.3,50 \mathrm{mM}$ of each dNTP, 2.5 units of Amplitaq polymerase and $0.4 \mu \mathrm{M}$ of each primer. Each reaction was overlayed with $50 \mu \mathrm{l}$ silicone oil and heated to $95^{\circ} \mathrm{C}$ for $2 \mathrm{~min}$. PCR was carried out essentially as previously described (Zwingman et al., 1993) for 25-29 cycles with the outer primers, and 30-35 cycles with the inner, nested primers at the appropriate annealing temperatures for each set (see Table 1). For the nested PCR, $1 \mu \mathrm{l}$ of primary product was added to $29 \mu \mathrm{l}$ of freshly prepared mix as above. The amplified product was electrophoresed on $2 \%$ Nusieve (FMC Bioproducts), $1 \%$ agarose or $9 \%$ polyacrylamide gels and stained with ethidium bromide.

Table 1 Oligonucleotide primers used for RT-PCR assays

\begin{tabular}{|c|c|c|c|c|c|}
\hline Gene & $\begin{array}{l}\text { Primer } \\
\text { type }\end{array}$ & Forward primer & Reverse primer & $\begin{array}{l}\text { Anneal. } \\
\text { temp. } \\
\left({ }^{\circ} \mathrm{C}\right)\end{array}$ & $\begin{array}{l}\text { Product } \\
\text { length } \\
\text { (bp) }\end{array}$ \\
\hline \multirow[t]{2}{*}{$Z F X / Z F Y$} & Outer & 5'CATGATAGTGTAGTGGAAGCAGAAA-3' & $5^{\prime}$-CCTCTCCTACGATCACTTCCATATA-3' & 60 & 499 \\
\hline & Nested & 5'-TTGGTAGCAGACTGTGCC(CorT)CT-3' & 5'-AACCATCTTTTCCCTGGGAACA-3' & 60 & 357 \\
\hline \multirow[t]{2}{*}{$S R Y$} & Outer & 5'-GCGACCCATGAACGCATTCA-3' & 5'-GTACCGAAGCGGGATCTGCG-3' & 58 & 275 \\
\hline & Nested & 5'-TCAGAGGCGCAAGATGGCTC-3' & 5'-TTCTTCGGCAGCATCTTCGC-3' & 60 & 204 \\
\hline \multirow[t]{2}{*}{ HPRT } & Outer & $5^{\prime}$-CTCCGCCTCCTCCTCTGCT-3' & 5'-GCCTGACCAAGGAAAGCAAAG-3' & 50 & 528 \\
\hline & Nested & 5'-GCCGGCTCCGTTATGGCG-3' & $5^{\prime}$-AGCCCCCCTTGAGCACACAGA-3' & 55 & 226 \\
\hline
\end{tabular}

a Previously published sequence (Palmer et al., 1990). 
A

B

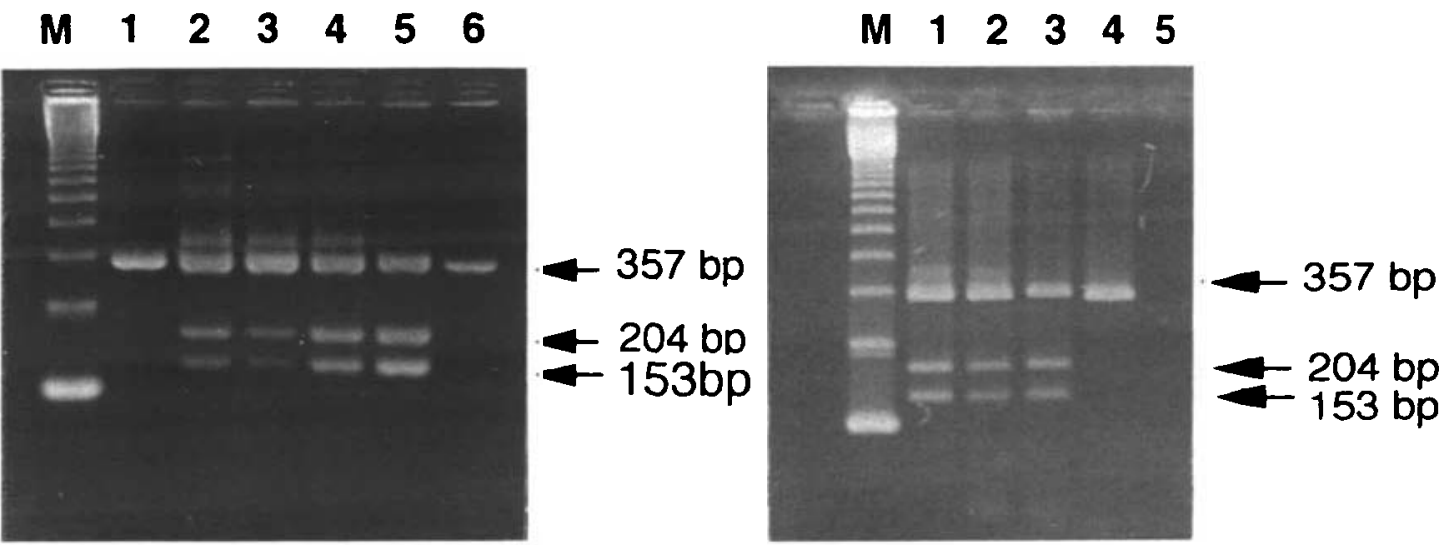

Figure 1 RT-PCR analysis of oocyte and preimplantation stage embryos for ZFX and ZFY transcription. RT-PCR was performed on RNAs from pooled oocytes, polyspermic zygotes and normal embryo samples (16 oocytes, 18 1-cell polyspermic zygotes, 15 2-cell, 204 to 8-cell, 8 morulae, 5 blastocysts). PCR products were digested with Cla I and resolved on a $2 \%$ Nusieve $1 \%$ agarose gel. $(A)$ Lanes: 1 , oocyte; 2,4 to 8-cell; 3, morula; 4, blastocyst; 5 , adult testis; 6 , adult female spleen. (B) Lanes: 1 , 2-cell; 2, 1-cell zygote; 3 , adult testis; 4 , oocyte; $5, \mathrm{H}_{2} \mathrm{O}$ control. $\mathrm{M}, 123$ bp DNA marker. The $Z F X$ product was 357 bp and $Z F Y$ products were $204 \mathrm{bp}$ and $153 \mathrm{bp}$.

\section{PCR Sequencing}

ZFX/ZFY and SRY PCR products from oocytes and embryos were reamplified using the conditions described above and purified with the PCR purification spin kit (Quiagen). Sequencing was completed with the 'fmol' DNA sequencing system (Promega) using forward and reverse nested primers.

\section{Results}

cDNA samples were prepared from pooled oocytes and embryos, as only half were expected to be male, for analysis of the transcription of $Z F Y$ and $S R Y$ genes. The oligonucleotide primers used to analyse $Z F Y$ transcripts also amplify the homologue, ZFX, on the $X$ chromosome (Palmer et al., 1990). Nested primers were designed to anneal at the same temperature as the outer primer to minimise non-specific bands. On digestion with restriction enzyme Cla I, the two gene transcripts can be distinguished such that the expression of $X$ or $Y$ transcripts in different samples can be determined. The nested primers for $Z F X / Z F Y$ give a $357 \mathrm{bp}$ band, and on digestion with ClaI ZFY transcripts give two bands corresponding to $204 \mathrm{bp}$ and $153 \mathrm{bp}$. This is due to the presence of a Cla I site in the $Z F Y$ sequence which is absent in ZFX. In addition, the outer primers are known to span an intron (Palmer et al., 1990), thus eliminating the possibility of genomic DNA contamination. Fig $1 A$ shows the pattern of ZFX/ZFY expression at different stages from unfertilised oocytes and 4- to 8-cell to the blastocyst stages. A $357 \mathrm{bp}$ product was obtained after nested PCR at all stages. On digestion with $\mathrm{Cla} \mathrm{I}$ (Fig. $1 A$ ), the product from cleavage and blastocyst stage embryos yielded two fragments of $204 \mathrm{bp}$ and $153 \mathrm{bp}$ corresponding to $Z F Y$ transcripts in addition to ZFX bands. Similarly, the adult testis control yielded all three bands for $Z F X$ and $Z F Y$ genes, whereas the female adult spleen yielded only the single $Z F X$ band. The $Z F X$ transcripts in unfertilised oocytes must be maternally inherited. However, our RT-PCR analysis is not quantitative; therefore the maternal or embryonic origin of ZFX transcripts detected at later stages cannot be distinguished.

We also studied the time of onset of $Z F Y$ transcription at earlier stages. Fig. $1 B$ shows the presence of $Z F Y$ transcripts as early as the pronuclear stage (20-24 $\mathrm{h}$ post-insemination) and later at the 2-cell stage, whereas the unfertilised oocyte control (Fig. 1B, lane 4) again showed only ZFX transcsripts. Previous studies have shown that both $Z F X$ and $Z F Y$ are expressed in a wide range of fetal and adult tissues (Palmer et al., 1990). We tested the expression of both genes in fetal male and female intestine, liver, lung, muscle, brain and kidney, and in adult male lung and female spleen. The results confirmed the previous findings that $Z F X$ was expressed in both male and female tissues whereas $Z F Y$ is expressed only in male tissues (results not shown). To further strengthen the conclusion, the RT-PCR products from oocytes and embryos were sequenced. Sequence analysis on oocyte (Fig. $2 A, B$ ) and embryo products (Fig. $2 C, D$ ) were performed with forward and reverse nested primers, respectively. With oocyte product, the sequence was identical to ZFX. The embryo product 
A
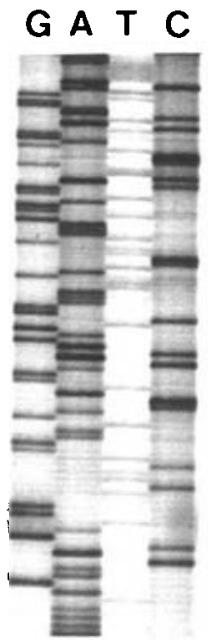

B

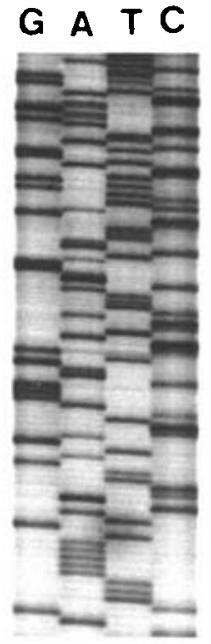

C

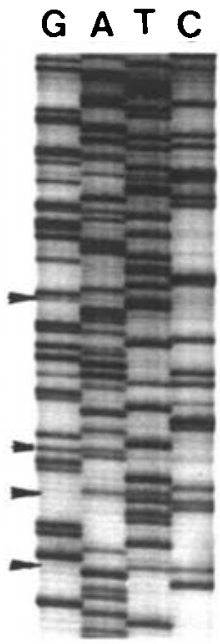

D

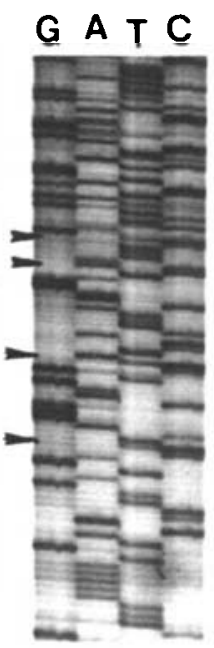

Figure 2 Sequence analysis on oocyte and embryo $Z F X / Z F Y$ RT-PCR products. Lanes $A$ and $B$, the oocyte product, and lanes $C$ and $D$, the embryo product, were sequenced with forward and reverse nested primers. Some sites are indicated at which two bases are found in embryos but not in oocytes.

sequence was a mixture of $Z F X$ and $Z F Y$ products, i.e. at the 17 positions at which the two differ in this span, bases for both sequences were found. Eight of the 17 positions at which ZFX and ZFY differ (Palmer et al., 1990 ) are indicated in the embryo sequencing lanes.

We also sought $S R Y$ transcription in oocytes, preimplantation embryos and human adult testis. $S R Y$ transcripts (204 bp) were present in adults testis and embryo samples, but not in oocytes. Amplification of HPRT transcripts from each sample confirmed that cDNA was present (Fig. $3 A$ ). SRY transcripts were present at the earliest preimplantation stage tested, the 2-cell stage, and also at the blastocyst stage (Fig. $3 B$ ). Sequence analysis of the product confirmed the identity as $S R Y$ (results not shown). Sequences corresponding to positions 234 to 344 from the forward nested primer and sequences corresponding to positions 264 to 160 from reverse nested primer were identical to the $S R Y$ published sequence (using the numbering of Gubbay et al., 1990).

\section{Discussion}

Global activation of the human embryonic genome is thought to occur between the 4- and 8-cell stage on day 2 post-insemination. Evidence for this includes qualitative changes in polypeptide synthesis during this period which are sensitive to transcriptional inhibition with $\alpha$-amanitin (Braude et al., 1989). Also, cleavage is initially insensitive to transcriptional inhibition
A

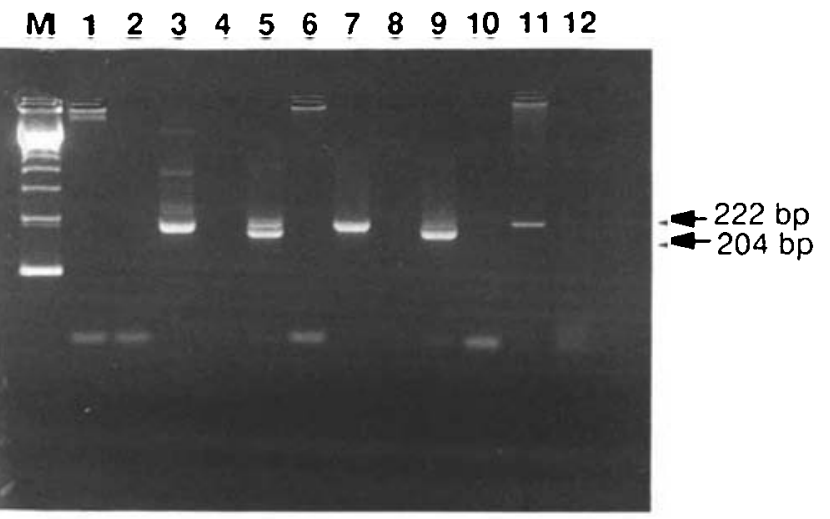

B

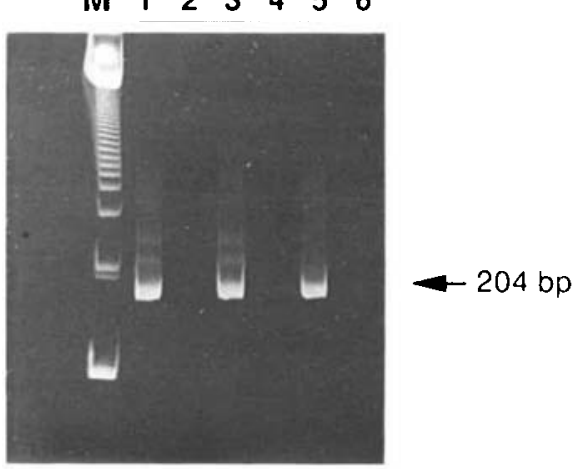

Figure 3 Transcriptional analysis of $S R Y$ expression in preimplantation embryos. RT-PCR was performed on RNAs from pooled oocytes and normal embryos. (16 oocytes, 8 2-cell, 5 blastocysts and 18 polyspermic mixed stage embryos). (A) Lanes 1, 5 and 9 were $\mathrm{RT}^{+}$samples with $S R Y$ primers and lanes 3,7 and 11 were $\mathrm{RT}^{+}$samples with HPRT primers for oocytes, adult testis and polyspermic (mixed stages) embryos respectively. Lanes 2,6 and 10 were $\mathrm{RT}^{-}$ samples with $S R Y$ primers and lanes $4,8,12$ were $\mathrm{RT}^{-}$ samples with HPRT primers for oocytes, adult testis and polyspermic embryos respectively. $(B)$ Lanes 1,3 and 5 were $\mathrm{RT}^{+}$samples with $S R Y$ primers for 2-cell, blastocyst and adult testis and lanes 2,4 and 6 were corresponding $\mathrm{RT}^{-}$ samples with $S R Y$ primers. $M, 123$ bp DNA molecular weight marker.

but is blocked at later stages, suggesting that early development is controlled by maternally inherited products (Braude et al., 1988). In the mouse, numerous studies have documented the onset of embryonic gene expression at the 2-cell stage (Flach et al., 1982; Bensaude et al., 1983; Bolton et al., 1984) accompanied by the degradation of maternal mRNA (Bachvarova \& De Leon, 1980; Giebelhaus et al., 1983; Graves et al., 1985. Paynton et al., 1988). In the human, similar studies are difficult mainly due to the limited availability of material. Transcription of hCG- $\beta$ has been reported as early as the 6- to 8-cell stage (Bonduelle et al., 1988), however, using in situ hybridisation. 
The recent development of sensitive RT-PCR methods has enabled us to examine transcripts in small numbers of human oocytes and embryos including, for example, transcription of epidermal growth factor and its receptor (M. Chia and A.H. Handyside, unpublished data). While it could be argued that these sensitive techniques might detect 'ectopic' transcripts (Chelly et al., 1989; Roberts et al., 1992), their sensitivity is not excessive considering the minute amount of starting material. The presence of paternal Y-linked transcripts before global activation of the embryonic genome at the 4- to 8-cell stage, ZFY as early as the pronucleate stage (Fig. $1 B$ ) and $S R Y$ at the 2-cell stage (Fig. 3B), is unexpected and suggests that at least some genes are actively transcribed earlier than previously thought. Furthermore, analysis of SRY transcripts at the 1-cell stage, which was not attempted by us, has been reported independently (E. Pergament and D.A. Rappolee, personal communication). Both Y-linked transcripts, therefore, are present during the first cycle after fertilisation. Similar observations indicating early transcription were recently reported for maternal and paternal Mhc class I genes transcripts in the mouse zygote, also using RT-PCR (Sprinks et al., 1993).

The possibility that these transcripts are derived from the fertilising sperm seems unlikely but cannot be ruled out. c-myc transcripts have been detected in mature ejaculated sperm cells in the human (Kumar et al., 1993). However, SRY transcripts were not detectable in washed sperm prepared in the same way as the other samples (data not shown). As antibodies to the $Z F Y$ and $S R Y$ products are not available, we were not able to confirm expression at the protein level. However, it seems likely that both genes are expressed, raising interesting questions concerning their functions at such an early stage of development.

Several recent findings have demonstrated that there is a differential growth rate between male and female, $X X$ and $X Y$ embryos in several mammalian species. At preimplantation stages, male embryos have a faster cleavage rate than female embryos in both mice (Tsunoda et al., 1985; Zwingman et al., 1993; Bourgoyne, 1993) and cattle (Avery et al., 1992; Xu et al., 1992). Recently Pergament et al. (1994) reported that significantly more males are born when the mean number of cells per embryo is 4 or greater at the time of embryo transfer on day $2,40-48 \mathrm{~h}$ post-insemination. Differences have also been observed at postimplantation stages, with male fetuses showing increased weight in rats (Scott \& Holsen, 1977), somite numbers in mice (Seller \& Perkins-Cole, 1987) and in first trimester human fetuses (Pedersen, 1980).

Mittwoch (1969, 1993; Mittwoch \& Mahadevaiah, 1980 ) has suggested that a faster growth rate results in the development of a testis and that slow growth leads to the formation of ovary. It is possible that differences in the growth of fetal gonads may be attributed to the presence of a growth factor activity encoded by the $Y$ chromosome. Alternatively, differences could result from the presence of a paternally imprinted $X$ chromosome in female $\mathrm{XX}$ embryos. In mouse, Bourgoyne (1993) has used genetic crosses to confirm that the growth rate difference in preimplantation embryos is Y-linked.

The cloning of SRY/Sry in man and mouse (Sinclair et al., 1990; Gubbay et al., 1990) and sex reversal of $40, X X$ mice transgenic for the Sry gene (Koopman et al., 1991) provide evidence that Sry is the Tdy. Transcription of Sry was first reported in developing gonadal ridges at 10.5 days post coitum, which was considered appropriate for Tdy (Koopman et al., 1991). We have shown transcription of Sry and Zfy at a much earlier stage, the 2-cell stage, with persistence of mRNA to the blastocyst stage (Zwingman et al., 1993). Our finding of similar results in the human embryo, i.e. transcription of $S R Y$ and $Z F Y$ in early preimplantation stages (and confirmed for $S R Y$ by E. Pergament \& D.A. Rappolee, personal communication) and differences in rate of development of male and female embryos (Pergament et al., 1994) focuses attention on the role of events in sex determination prior to gonadal differentiation.

Previously male and female preimplantation embryos have been shown to differ for expression of the male specific antigen (MSA, serological H-Y). This has been found in mice (Krco \& Goldberg, 1976; Epstein et al., 1980), cattle (White et al., 1987a), sheep (White et al., 1987b), pigs (White et al., 1987c), and horse blastocysts (Wood et al., 1988). In all cases, half the embryos are reactive and, when karyotypes have been performed, only Y-bearing embryos are antigen positive. Although once a candidate sex determination factor, it now seems that the gene may be located on an autosome (Lau et al., 1989), but its expression establishes the fact that not only transcription but also translation differs between mammalian male and female preimplantation embryos.

The mechanism by which SRY or ZFY expression could lead to more rapid growth of the Y-bearing preimplantation embryo has yet to be determined. Similarly, the relationship between more rapid growth and sexual differentiation (if any, since the two phenomenona may not be causally related) is unclear. However, the relationship may not depend on testosterone and müllerian inhibiting substance as second messengers.

\section{Acknowledgements}

The authors would like to thank Karin Dawson and the IVF team for their help. We are grateful to Dr S. 
Povey and $\mathrm{Mr} \mathrm{G}$. Williams for providing tissue samples, Ms S. Loughna for RNA samples and P. Ray and $M$. Chia for their help in designing primers. We also thank Diana Davis and Penny Graves for assistance. R.P.E. was supported by funds from the Department of Paediatrics, University of Arizona.

\section{References}

Avery, B., Jorgensen, C.B., Madison, V. \& Grere, T. (1992). Morphological development and sex of bovine in vitrofertilized embryos. Mol. Reprod. Dev. 32, 265-70.

Bachvarova, R. \& De Leon, V. (1980). Polyadenylated RNA of the mouse ova and loss of maternal RNA in early development. Dev. Biol. 74, 1-8.

Bensaude, O., Babinet, C., Morange, M. \& Jacob, F. (1983). Heat shock proteins, first major products of zygotic gene activity. Nature 305, 331-3.

Bolton, V.N., Oades, P.J. \& Johnson, M.H. (1984). The relationship between cleavage, DNA replication, and gene expression in the mouse 2-cell embryo. J. Embryol. Exp. Morphol. 79, 139-63.

Bonduelle, M.L., Dodd, R., Leibaers, I., Van Steirteghem, A., Williamson, R. \& Akhurst, T. (1988). Chorionic gonadotrophin- $\beta$ mRNA, a trophoblast marker, is expressed in human 8-cell embryos derived from tripronucleate zygotes. Hum. Reprod. 83, 909-14.

Bourgoyne, P.S. (1993). A Y-chromosomal effect on blastocyst cell number in mice. Development 117, 341-5.

Braude, P., Pelham, H., Flach, G. \& Lobatto, R. (1979). Posttranscriptional control in the early mouse embryo. Nature 282, 102-5.

Braude, P., Bolton, V. \& Moore, S. (1988). Human gene expression first occurs between the four- and eight-cell stages of preimplantation development. Nature 332, $450-61$.

Camouse, S., Kopecny, V. \& Flechon, J.E. (1986). Autoradiographic detection of the earliest stage of ${ }^{3} \mathrm{H}$-uridine incorporation in the cow embryo. Biology of Cell 58, 195-200.

Chelly, J., Concordet, J.-P., Kaplan, J.-C. \& Kahn, A. (1989). Illegitimate transcription: transcription of any gene in any cell type. Proc. Natl. Acad. Sci. USA 86, 2617-21.

Clegg, K.B. \& Piko, L. (1982). RNA synthesis and cytoplasmic polyadenylation in the one-cell mouse embryo. Nature 295, 342-5.

Clegg, K.B. \& Piko, L. (1983a). Quantitative aspects of RNA synthesis and polyadenylation in 1-cell and 2-cell mouse embryos. J. Embryol. Exp. Morphol. 74, 169-82,

Clegg, K.B. \& Piko, L. (1983b). Poly(A) length, cytoplasmic adenylation and synthesis of poly $(A)^{+}$RNA in early mouse embryo. Devel. Biol. 95, 331-41.

Crosby, I.M., Gandolfi, F. \& Moor, R.M. (1988). Control of protein synthesis during early cleavage of sheep embryos. J. Reprod. Fert. 82, 769-75.

Epstein, C.J., Smith, S. \& Davis, B. (1980). Expression of H-Y antigen on preimplantation mouse embryos. Tissue Antigens 15, 63-7.

Flach, G., Johnson, M.H., Braude, P.R., Taylor, R.A.S. \& Bolton, V.N. (1982). The transcription from maternal to embryonic control in 2-cell mouse embryo. EMBO J. 1, 681-6.
Giebelhaus, D.H., Heikkila, J.J. \& Schultz, G.A. (1983). Changes in the quantity of histon and actin mRNA during the development of preimplantation mouse embryos. Dev. Biol. 98, 148-54.

Gilliland, G., Perrin, S. \& Bunn, H.F. (1990). In: PCR Protocols: $A$ Guide to Methods and Applications, ed. M.A. Innis, D.H. Gelfand, J.H. Sninsky \& T.J. White, pp.60-9. Academic Press, New York.

Graves, R.A., Marzluff, W.F., Gierelhaus, D.H. \& Schultz, G.A. (1985). Qualitative and quantitative changes in histon gene expression during early mouse embryo development. Proc. Natl. Acad. Sci. USA 82, 5685-9.

Gubbay, J., Collignon, J., Koopman, P., Capel, B., Economou, A., Munsterberg, A., Vivian, N., Goodfellow, P. \& LovellBadge, R. (1990). A gene mapping to the sex determining region of the mouse $Y$ chromosome is a member of a novel family of embryonically expressed genes. Nature 346, 245-50.

Hardy, K., Handyside, A.H. \& Winston, R.M.L. (1989). The human blastocyst: cell number, death and allocation during late preimplantation development in vitro. Development 107, 597-604.

Koopman, P., Munsterberg, A., Capel, B., Vivian, N. \& LovellBadge, R. (1990). Expression of sex-determining gene during mouse testis differentiation. Nature 348, 450-2.

Koopman, P., Gubbay, J., Vivian, N., Goodfellow, P. \& Lovell-Badge, R. (1991). Male development of chromosomally female mice transgenic for Sry. Nature 351, 117-21.

Krco, C.J. \& Goldberg, E.H. (1976). Detection of H-Y (male) antigen and 8-cell mouse embryos. Science 193, 1134-5.

Kumar, G., Patel, D. \& Naz, R.K. (1993). c-MYC mRNA is present in human sperm cells. Cell. Mol. Biol. Res. 39, 111-17.

Lau, Y.-F.C., Chan, K. \& Sparks, R. (1989). Male-enhanced antigen gene is phylogenetically conserved and expressed at late stages of spermatogenesis. Proc. Natl. Acad. Sci. USA 86, 8462-6.

Mittwoch, U. (1969). Do genes determine sex? Nature 221, 446-8.

Mittwoch, U. (1993). Blastocysts prepare for the race to be male. Hum. Reprod. 8, 1550-5.

Mittwoch, U. \& Mahadevaiah, S. (1980). Comparision of development of human fetal gonads and kidneys. Growth 44, 287-300.

Page, C.C., Mosher, R., Simpson, E.M., Fisher, E.M.C., Mardon, G., Pollack, J., McGillivray, B., de la Chapelle, A. \& Brown, L.G. (1987). The sex determining region of the human $Y$ chromosome encodes a finger protein. Cell 51, 1091-104.

Palmer, M.S., Besta, P., Sinclair, A.H., Pym, B. \& Goodfellow, P.N. (1990). Comparision of human ZFY and ZFX transcripts. Proc. Natl. Acad. Sci. USA 87, 1681-5.

Paynton, B.V., Rempel, R. \& Bachvarova, R. (1988). Changes in state of adenylation and time course of degradation of mRNAs during oocyte maturation and early embryonic development in the mouse. Dev. Biol. 129, 304-14.

Pedersen, J.F. (1980). Ultrasound evidence of sexual difference in fetal size in first trimester. BMJ 281, 1253.

Pergament, E., Fiddler, M., Cho, N., Johnson, D. \& Holmgren, W.J. (1994). Sexual differentiation and preimplantation cell growth. Hum. Reprod. 9, 1730-1732. 
Roberts, R.G., Bobrow, M. \& Bentley, D.R. (1992). Point mutation in the dystophin gene. Proc. Natl. Acad. Sci. USA $199289,2331-5$

Rutherford, A.J., Subak-Sharpe, R., Dawson, K., Margara, R.A., Franks, S. \& Winston, R.M.L. (1988). Dramatic improvement in IVF success following treatment with LHRH agonist. BMJ 296, 1765-8.

Scott, W.J., Holsen, J.F. (1977). Weight differences in rat embryos prior to sexual differentiation. J. Embryol. Exp. Morphol. 40, 259-63.

Seller, M.J. \& Perkins-Cole, K.J. (1987). Sex differences in mouse embryonic development at neurulation. J. Reprod. Fert. 79, 159-61.

Sinclair, A.H., Berta, P., Palmer, M.S., Hawkins, J.R., Griffiths, B.L., Smith, M.J., Foster, J.W., Frischauf, A.M., LovellBadge, R. \& Goodfellow, P.N. (1990). A gene from the human sex determining region encodes a protein with homology to a conserved DNA binding motif. Nature 346, $240-4$.

Sprinks, M.T., Selleus, M.H., Dealtry, G.B. \& Fernandez, N. (1993). Preimplantation mouse embryos express Mhc class I genes before the first cleavage division. Immunogenetics $39,35-40$.

Tesarik, J. \& Kopecny, V. (1989). Nucleic acid synthesis and development of human male pronucleus. J. Reprod. Fert. 86, 549-58.

Tesarik, J., Kopecny, V., Plachot, M. \& Mandelbaum, J. (1988). Early morphological signs of embryonic genome expression in human preimplantation development as revealed by quantitative electron microscopy. Dev. Biol. $128,15-20$.
Tomanek, M., Kopecny, V. \& Kanaka, J. (1989). Genome reactivation in developing early pig embryos: an ultrastructural and autoradiographic analysis. Anat. Embryol. $180,309-16$.

Tsunoda, Y., Tokunaga, T. \& Sugie, T. (1985). Altered sex ratio of live young after transfer of fast-and slow-developing mouse embryos. Gamete Res. 12, 301-4.

White, K.L., Anderson, G.B. \& Bon Durant, R.H. (1987a). Expression of a male-specific factor on various stages of preimplantation bovine embryos. Biol. Reprod. 37, 867-73.

White, K.L., Anderson, G.B., Pashen, R.L. \& Bon Durant, R.H.J. (1987b). Detection of histocompatibility ${ }^{-y}$ (H-Y) antigen: identification of sex of preimplantation ovine embryos. J. Reprod. Immunol. 10, 27-32.

White, K.L., Anderson, G.B., Berger, T.J., Bon Durant, R.H. \& Pashen, R.L. (1987c). Identification of a male-specific histocompatibility protein on preimplantation porcine embryos. Gamete Res. 17, 107-13.

Wood, T.G., White, K.L., Thompson, D.L. Jr \& Garza, F. Jr (1988). Evaluation of the expression of a male-specific antigen on cells of equine blastocysts. J. Reprod. Immunol. $14,1-8$.

Xu, K.P., Yadav, B.R., King, W.A. \& Betteridge, K.J. (1992). Sex related differences in developmental rates of bovine embryos produced and cultured in vitro. Mol. Reprod. Dev. 31, 229-34.

Zwingman, T., Erickson, R.P., Boyer, T. \& Ao, A. (1993). Transcription of the sex determining region genes sry and zfy in the mouse preimplantation embryo. Proc. Natl. Acad. Sci. USA 90, 814-17. 